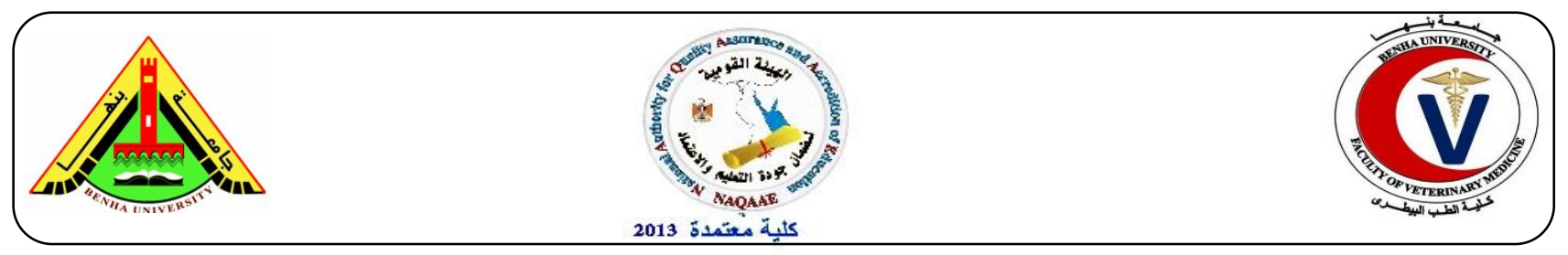

\title{
Genetic analysis of blood protein and COMET assay on the ovary in relation to reproductive performance in she-camel (C. dromedaries)
}

\author{
Amany Farouk ${ }^{1}$, H. M. Hassan ${ }^{2}$, M. A. Agag ${ }^{1}$, Hadeel S. El-Qaliouby ${ }^{3}$, \\ G. A. Sosa ${ }^{1}$, A. I. EL-Azab ${ }^{1}$ \\ ${ }^{1}$ Theriogenology Dept., Faculty of Veterinary Medicine, Benha University. \\ ${ }^{2}$ Diagnosis Research Institute, Egypt. \\ ${ }^{3}$ Animal Wealth Development Dept., Faculty of Veterinary Medicine, Benha University.
}

\section{ABSTRACT}

The present work was planned to study the changes in the ovarian cytogenesis (biochemical electrophoresis to detect the genotypes of some plasma proteins) of female camels during the breeding and the non-breeding seasons. Ovaries from 57 she-camels (C. dromedarius) were collected (37 ovaries during the breeding season and 20 ovaries during non-breeding season). Serum protein, types of allels and their mean $\%$ in the breeding and nonbreeding seasons were recorded. COMET assay was used to measure DNA damage in cells. DNA strand breaks were represented by the mean for 9 COMETs / sample. The mean \pm SD of COMET \% in the right ovary in breeding and nonbreeding seasons were 13.6 \pm 1.26 and $16.1 \pm 1.31$ in tailed DNA, while in non tailed DNA were $90.1 \pm 0.56$ and $85.8 \pm 1.26$ in breeding and nonbreeding seasons respectively. The mean \pm SD of COMET in the left ovary in breeding and nonbreeding seasons were $12.6 \pm 1.03$ and $15.5 \pm 0.05$ in tailed DNA, while in non tailed DNA were $91.1 \pm 0.73$ and $84.5 \pm 2.77$ in breeding and nonbreeding seasons respectively. The results showed non significant variations between right and left ovaries in DNA damage. While the mean \pm SD of COMET $\%$ in the right and left ovaries recorded significant variations between seasons in both tailed and non tailed DNA. By single cell gel electrophoresis, it was noticed that apoptotic cells could be clearly distinguished from un-apoptotic cells by the pattern of the COMET image.

Key words: Genetic analysis ovary reproductive performance camel COMET image.

(http://www.bvmj.bu.edu.eg)

(BVMJ-35(2): 422-435, 2018)

\section{INTRODUCTION}

Although, as camels are generally used in less well-developed countries, research into improving characteristics such as fertility, milk and meat production have been lacking. However, the development of camel racing in the Middle East has led to an increase in value of the racing dromedary and thus increased interest in improving reproductive efficiency (Fernández-Baca, 1993). 
Genetic analysis of blood protein and COMET assay on the ovary in relation to reproductive performance in shecamel (C. dromedaries)

Physiology of the ovary usually signals the capability of the ovaries to produce fertile ova and reproductive hormones that can influence the maturity of the ova for optimum fertilization. Hence, the need to evaluate the abnormalities of the ovaries as they are frequently attributed to compromise the ovarian activities which can result into infertility and sterility depends on the level of anatomical defects found on the ovaries (Iliyasu et al., 2016). Opportunities to improve reproductive efficiency of dromedary camel are limited by different constrains as semen characteristics, long gestation period of 13 months, late sexual puberty and maturity, limited breeding season, mechanism of estrous cycle and the lack of use of assisted reproductive techniques such as embryo transfer and artificial insemination (Adams et al., 1990). AI would also be of use for the international movement of genetics (Deen, 2008).

The female camel is a seasonal breeder, induced ovulator animals mainly ovulation induction is initiated by coitus, whereas during the rest of the year the ovaries remained inactive and showed limited number of very small follicles. There was a significant difference in ovarian activity between different months, as well in different seasons (Brown, 2000; Nawar et al., 2001).

The analysis of biochemical parameters in she camel through breeding was used as a method to measure the relative of genetic variation. As electrophoresis is easily performed and requires only a small sample volume, detailed analysis of serum protein electrophoretic pattern by the evaluation of protein has great diagnostic potential for the detection of genetic polymorphism. The determination of serum proteins and their electrophoretic profiles was used as an important diagnostic aid in clinical biochemistry. Acrylamide gel electrophoresis in the presence of sodium dodecyl sulfate has become one of the most widely used techniques to separate and characterize serum proteins based on their size and electrical charge (Navajas and Fenton, 2000; Taylor et al., 2010). The protein bands are usually divided into albumin, alpha $(\alpha)$-, beta $(\beta)$ - and gamma $(\gamma)$ globulins, while $\alpha$ - and $\beta$-globulins are further divided into alpha1 ( $\alpha 1)$ - and alpha2 ( $\alpha 2)$-, and beta1( $\beta 1)$ - and beta 2 ( $\beta 2)$-globulins. The percentage contribution of each fraction multiplied by the total protein concentration provides approximate protein concentration for each fraction (Ahmadi-Hamedani et al., 2014; Benmoussa et al., 2000; Minde et al., 2012). The pattern of serum protein electrophoresis results depends on the fractions of two major types of proteins; albumin and globulins (Bruss and Editors, 2000). Many pathological conditions can cause shifts in albumin and globulin concentrations (Keay and Doxey, 1982). Moreover, abnormalities of serum protein electrophoretic pattern must be interpreted in the view of the many other influences not associated with diseases. The age of evaluated animals is an important factor that may affect the concentrations of frequently analyzed biochemical variables and may also influence the serum protein electrophoretic profile (Fayos et al., 2005; Kaneko et al., 1997; 2013; Xu et al., 1985). Many authors stated that the most of biochemical parameters in young animals differ from the reference intervals used in adults (Bruss and Editors, 2000; Skidmore 2010). However, little work has focused on the 
various molecular processes, especially at the protein expression level, in terms of germ cell, follicular growth, and the mechanisms by which ovarian hormones regulate ovarian cycles, including follicular maturation, ovulation, and corpus luteum formation (Berek and MartinezMaza, 1994; Diao et al., 2004).

Number of techniques for detecting DNA damage as opposed to the biological effects (e.g micronuclei, mutations and structural chromosomal aberrations) that result from DNA damage, have been used to identify substances with genotoxic activity. Recently, the most frequently used methods involved either the detection of DNA repair synthesis is COMET assay. The COMET assay (single cell jell electrophoresis) is a simple standard method for assessing DNA damage, with application in genotoxicity testing as well as fundamental research in DNA damage and repair. Cells embedded in agarose on a microscope slide are lysed with detergent and high salt to form nucleoids containing supercoiled loops of DNA breaks (Collins, 2004 and Andrew, 2004). The appearance of a COMET reflects damage in the cellular DNA overall. It would be extremely informative to locate specific chromosomes, or regions of chromosomes, classes of DNA or specific genes within the COMET. When almost all the DNA is in the tail of a COMET, the head is reduced in size, and the image has fancifully been referred to as hedgehog COMET, for some reason the idea has grown that hedgehog COMETs represent apoptotic cells, lysing cells to liberate DNA, exposing the liberated DNA to alkali to produce single stranded DNA (Sinha et al., 1981). The single cell gel electrophoresis (COMET assay) can be used to investigate the genotoxicity of industrial chemicals bioacides, agrochemicals and pharmaceuticals. COMET assay detects DNA fragments out of the nucleus to form the tail of a COMET like structure. The extent of migration of DNA fragments is an indication of DNA damage that can be quantified. In this respect, the COMET assay is promising tool because it is rapid, simple to perform, and requires only small amount of test substance (Cook (1976). The need for only very small amounts of test chemical, makes this assay an alternative tool to screen and verify the genotoxic property of chemicals. This assay has gained wide-spread use in various areas including human bio-monitoring, genotoxicology, ecological monitoring and as tool for research in to DNA damaging agents (Collins, 2004). The current study aimed to apply both biochemical electrophoresis as well as COMET assay to assess the ovarian function in female dromedary camel and its relation to reproductive efficiency.

\section{MATERIAL AND METHODS:}

\subsection{Animals:}

The present study was conducted on ovaries from 57 she-camels (C. dromedarius) collected during breeding and non breeding season (37 ovaries during the breeding season and 20 ovaries during non breeding season). The age ranged from 5-10 years was identified after dentation according to Agag (1991). All animals were apparently and clinically normal and slaughtered in Benha Abattoir, Qaliobia Province, Egypt, over a period of 12 months.

\subsection{Samples:}

2.2.1. Ovaries: Immediately after collection, ovaries from 57 cases were wrapped in plastic sheets, placed in an ice box and taken to the laboratory within one hour after slaughter. In the laboratory, the samples were stored in -20 deep freeze for COMET analysis. 
Genetic analysis of blood protein and COMET assay on the ovary in relation to reproductive performance in shecamel (C. dromedaries)

2.2.2. Blood: Blood samples were collected from the jugular vein into clean dry sterile and heparinized tubes during breeding and nonbreeding season, all collected blood samples were centrifuged for $5 \mathrm{~min}$. at 3000 r.p.m. Clean and clear plasma were aspirated carefully by Pasteur pipettes and transferred into dry sterile labeled Eppendorf tubes. The separated plasma was kept at $-20^{\circ} \mathrm{C}$, till being used for the electrophoresis and immune genetic analysis (Mayer and Fiechter, 2013).

\subsection{SDS (sodium dodecyl sulfate) Gel} Electrophoresis: SDS Gel electrophoresis was used to detect protein type $\alpha, \beta$ and $\gamma$ and to determine the size of the protein products. It was performed according to Caprette, (2009); Minde et al., (2012) and Rath et al., (2009). Electrophoresis of genotypes in some plasma proteins was applied by polyacrylamid gel electrophoresis (PAGE) (Masharov, 1980). Identification of any single protein bounds and distribution of genotypes and fractionation of blood protein was applied according to Masharov (1980).

2.3.1. COMET ASSAY: It was performed according to Sinha et al., (1981).

\subsection{Statistical analysis of the data:}

Analysis of the obtained data was applied using two-way analysis of variance and student's T-test using SPSS program (SPSS Inc., 2007).

\section{RESULTS:}

\subsection{Macroscopic examination}

Macroscopic examination of the ovary of she camel during the breeding season showed the presence of highly vascular multiple follicles. The cortex filled with different stages of the developing follicle (Fig, 1) while during the non-breeding season, the ovaries were nearly smooth consisted of small inactive multiple follicles (Fig, 2).

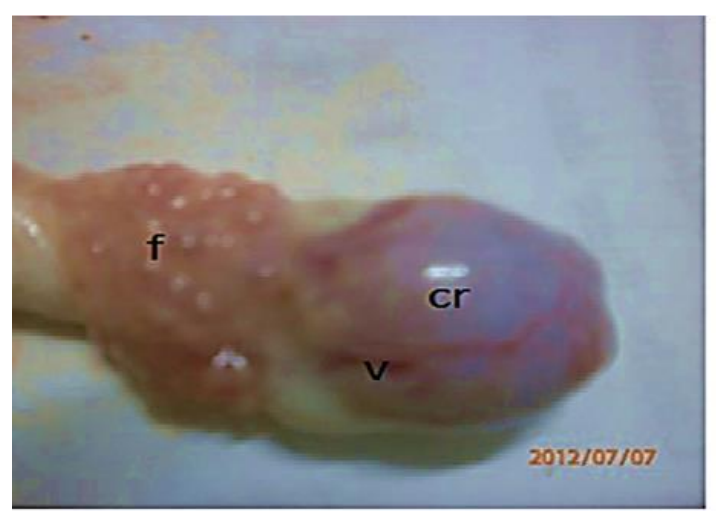

Fig. (1): The ovary of she camel during the breeding season. It showing multiple highly vascularized follicles ( $f-v)$ and corpus luteum (cr).

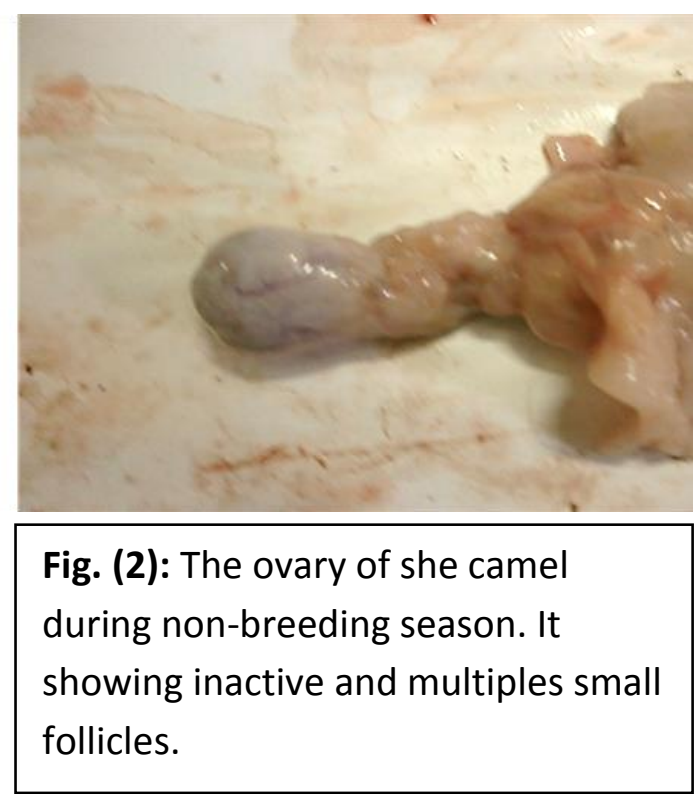




\subsection{Electrophoresis results}

3.2.1. Protein, types of allels and their mean \% in the breeding and nonbreeding seasons: As shown in table (1), Fig. $(3,4,5,6)$, the following were detected by electrophoretic analysis:

1-(albumin1); the mean percentage in breeding season characterized by high frequency of fJ $(45.9 \%)$ than in non-breeding season $\mathrm{JJ}$ which is not frequency $(40 \%)$.

2-(albumin 2); the mean percentage in breeding season characterized by not frequency in $\mathrm{JJ}$ $(32.4 \%)$ and in non-breeding season $\mathrm{FJ}$ is high frequency $(35 \%)$.

3- (albumin3); the mean percentage in breeding season characterized by not frequency in FF (18.9\%) and in non-breeding season $\mathrm{FF}$ is high frequency $(25 \%)$.

4- (Prealbumin 1 ); the mean percentage in breeding season characterized by high frequency in NS (48.6\%) and in nonbreeding $\mathrm{NN}$ is frequency $(25 \%)$.

5- (Prealbumin 2); the mean percentage in breeding season characterized by not frequency in NN (29.7) and in non breeding season NS (50\%) is high frequency

6- (Prealbumin3); the mean percentage in breeding season characterized by not frequency in SS (16.2\%) and in non-breeding season SS ( 20\%) is high frequency.

7- (Postalbumin1); the mean percentage in breeding season characterized by not frequency in DF (27.9\%) and in non-breeding season DF $(75 \%)$ is high frequency.

8-(Postalbumin2); the mean percent in breeding season characterized by high frequency (18.9\%) FF and in non-breeding season is characterized by not frequency $(15 \%)$ in DD

9- (Postalbumin3); the mean percentage in breeding season characterized by not frequency $*(08 \%)$ SS and in non-breeding season is frequency (10\%) FF.

10- (Transferrin 1); the mean percentage of breeding season characterized by not frequency DO (27\%) and in non-breeding season is high frequency (65\%) DF.

11- (Transferrin 2); the mean percentage in breeding season characterized by high frequency $\mathrm{OO}(29 \%)$ and in non-breeding season is characterized by not frequency in DD $(25 \%)$.

12- (Transferrin 3); the mean percentage in breeding season is characterized by high frequency in DD and in non breeding season is characterized by non-frequency in $\mathrm{FF}$

$(0.05 \%)$ 
Genetic analysis of blood protein and COMET assay on the ovary in relation to reproductive performance in shecamel (C. dromedaries)

Table (1):

showing

albumin,

prealbumin,

post albumin,

transferrin,

their types of

alleles and

mean \%

in breeding

and non-

breeding

seasons for

she camel.

\begin{tabular}{|c|c|c|c|c||}
\hline Protein & $\begin{array}{c}\text { Types } \\
\text { of } \\
\text { alleles }\end{array}$ & $\begin{array}{c}\text { Mean\% in } \\
\text { Breeding }\end{array}$ & $\begin{array}{c}\text { Types of } \\
\text { alleles }\end{array}$ & $\begin{array}{c}\text { Mean \% in } \\
\text { Non } \\
\text { breeding }\end{array}$ \\
\hline \hline Albumin & FJ & $45.9 \%$ & JJ & $40 \%$ \\
\hline & JJ & $32.4 \%$ & FJ & $35 \%$ \\
\hline & FF & $18.9 \%$ & FF & $25 \%$ \\
\hline \hline Prealbumin & NS & $48.6 \%$ & NN & $25 \%$ \\
\hline & NN & $29.7 \%$ & NS & $50 \%$ \\
\hline & SS & $16.2 \%$ & SS & $20 \%$ \\
\hline Postalbumin & DF & $27.9 \%$ & DF & $75 \%$ \\
\hline & Ff & $18.9 \%$ & DD & $15 \%$ \\
\hline & SS & $8 \%$ & FF & $10 \%$ \\
\hline Transferin & DO & $27 \%$ & DF & $65 \%$ \\
\hline & OO & $29 \%$ & DD & $25 \%$ \\
\hline & DD & $43.2 \%$ & FF & $0.5 \%$ \\
\hline
\end{tabular}

Table 2: The mean \pm SD for COMETs of both right and left ovary in breeding and nonbreeding seasons for she camel.

\begin{tabular}{|l|c|c|c|c|}
\hline \multirow{2}{*}{ Ovary } & \multicolumn{2}{|c|}{ Right ovary } & \multicolumn{2}{c|}{ Left ovary } \\
\cline { 2 - 5 } Season & $\begin{array}{c}\text { \% COMET } \\
\text { DNA of Tailed }\end{array}$ & $\begin{array}{c}\% \text { COMET } \\
\text { DNA of } \\
\text { Non-tailed }\end{array}$ & $\begin{array}{c}\text { \% COMET } \\
\text { DNA of Tailed }\end{array}$ & $\begin{array}{c}\% \text { COMET } \\
\text { DNA of } \\
\text { Non-tailed }\end{array}$ \\
\hline Breeding & $13.6 \pm 1.26^{\mathrm{a}}$ & $90.1 \pm 0.56^{\mathrm{c}}$ & $12.6 \pm 1.03^{\mathrm{a}}$ & $91.1 \pm 0.73^{\mathrm{c}}$ \\
\hline Non-breeding & $16 \pm 1.31^{\mathrm{b}}$ & $85.8 \pm 1.26^{\mathrm{d}}$ & $15.5 \pm 0.05^{\mathrm{b}}$ & $84.5 \pm 2.77^{\mathrm{d}}$ \\
\hline
\end{tabular}

*Values with the different superscripts in the same column were significantly different $(p<0.05)$ 
Farouk et al. (2018) BVMJ-35(2): 422-435.

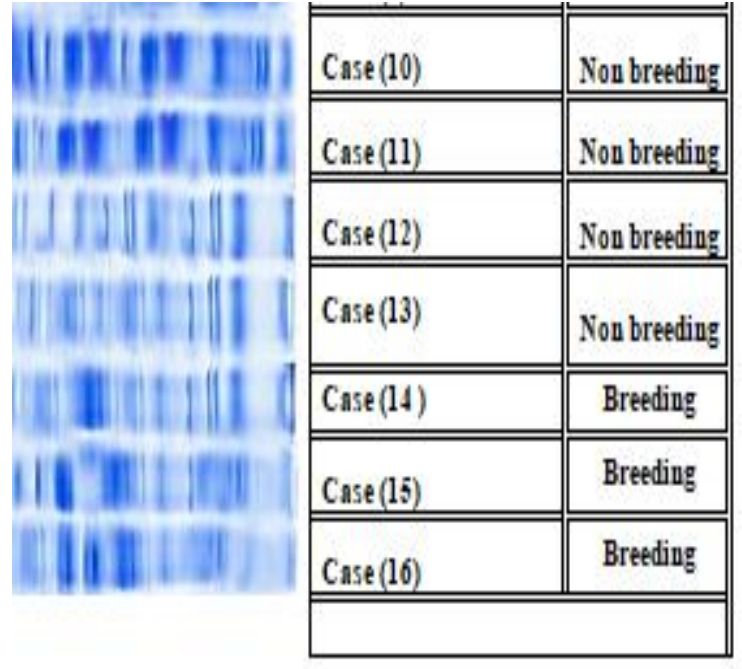

Fig 3: Protein electrophoresis (albumin, prealbumin, postalbumin, transferrin) in breeding and nonbreeding season (Samples 1-8)

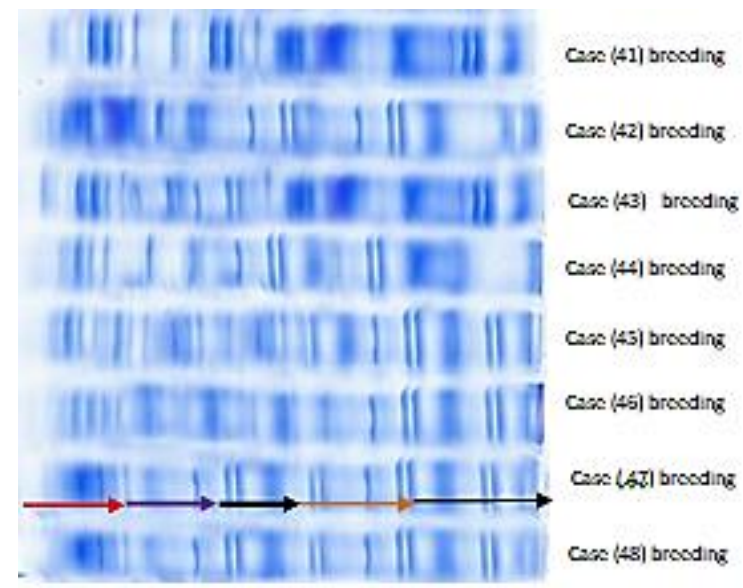

Fig 5: showing protein electrophoresis (albumin, prealbumin, postalbumin, transferrin) in breeding and nonbreeding season (Samples 41-48)

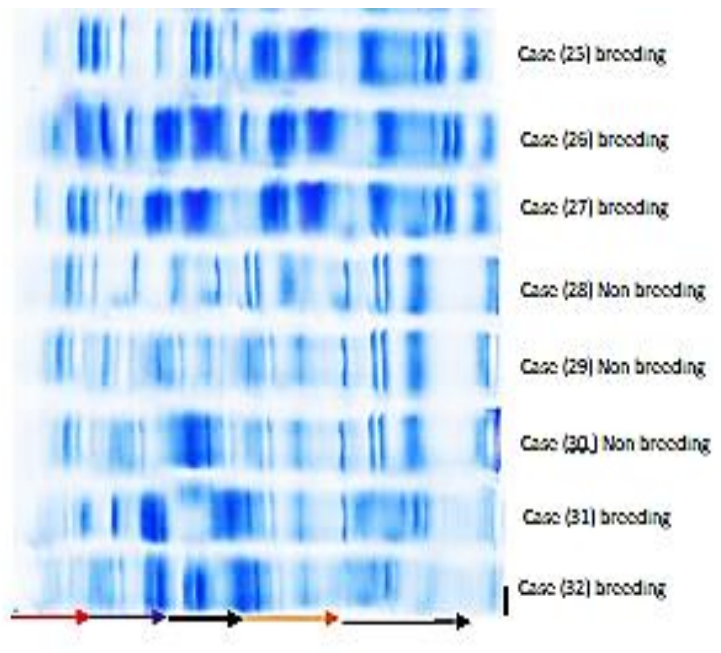

Fig 4: Protein electrophoresis (albumin, prealbumin, postalbumin, transferrin) in breeding and nonbreeding season (Samples 25-32)

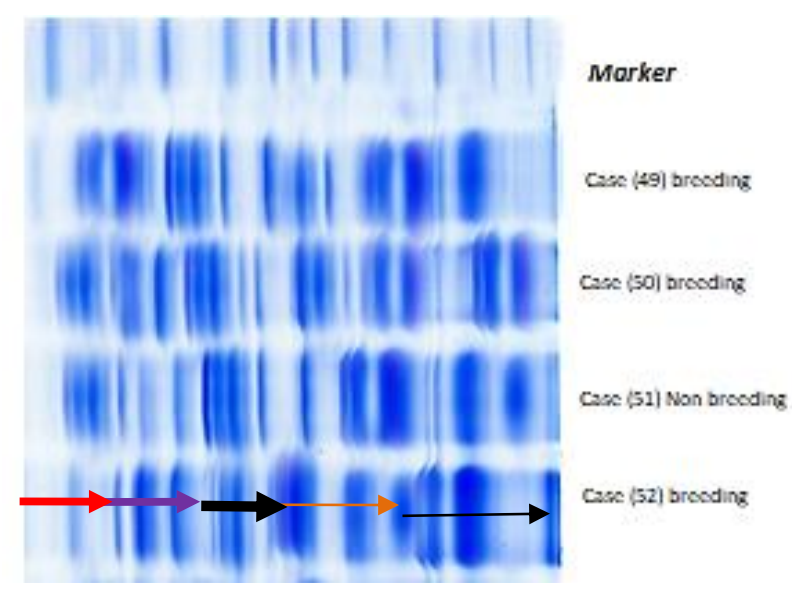

Fig 6: showing protein electrophoresis (albumin, prealbumin, postalbumin, transferrin) in breeding and non-breeding season (Samples 49-52) 


\section{Fig (7): DNA damage is calculated as the DNA tail area / whole DNA area (\%) and the COMET tail length (from the center of DNA Head to the end of the DNA Tail). The bigger the DNA tail area $(\%)$ or the longer the DNA tail length , the more significant the damage.}
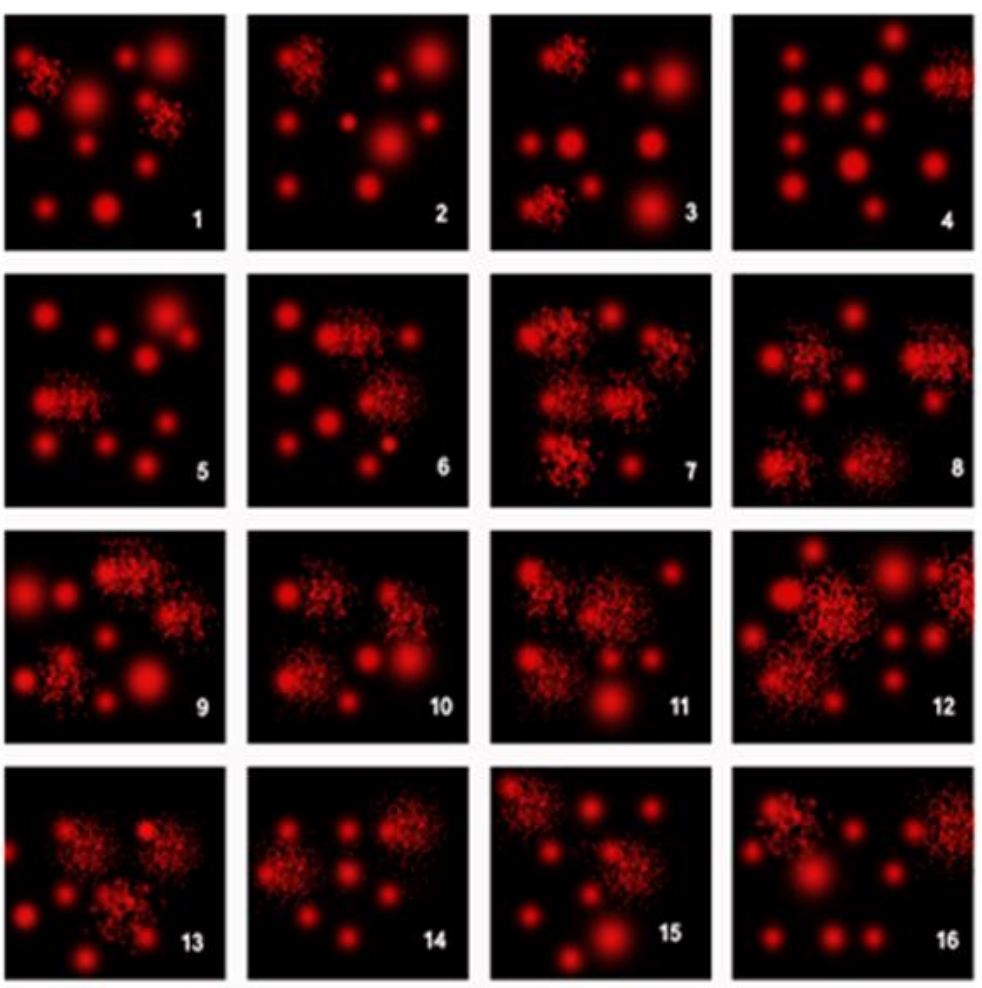

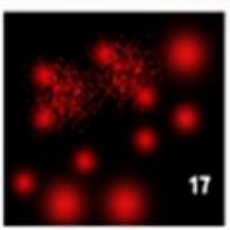

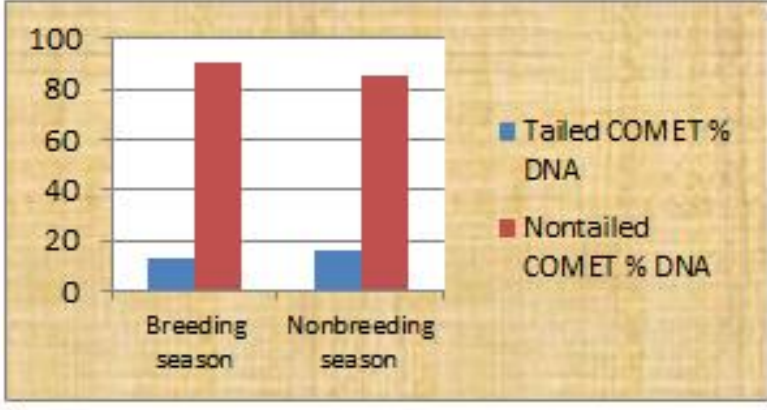

Fig. 8: Graph showing tailed and non-tailed COMET \% of DNA in the Rt. Ovary in both breeding and non-breeding seasons.

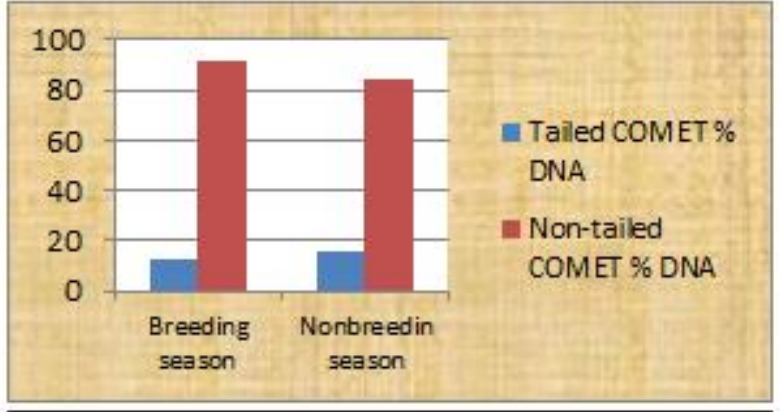

Fig. 9: Graph showing tailed and non-tailed COMET \% of DNA in the Lt.. Ovary in both breeding and non-breeding seasons. 


\subsection{COMET results}

COMET assay was used to measure DNA damage in cells. DNA strand breaks were represented by the mean for 9 COMETs / sample. As shown in table (2) and figure $(8,9)$, the mean \pm SD of COMET \% in the right ovary in breeding and nonbreeding seasons were 13.6 \pm 1.26 and $16.1 \pm 1.31$ in tailed DNA, while in non tailed DNA were $90.1 \pm 0.56$ and $85.8 \pm$ 1.26 in breeding and nonbreeding seasons respectively. The mean \pm SD of COMET in the left ovary in breeding and nonbreeding seasons were $12.6 \pm 1.03$ and $15.5 \pm 0.05$ in tailed DNA, while in non tailed DNA were $91.1 \pm$ 0.73 and $84.5 \pm 2.77$ in breeding and nonbreeding seasons respectively. The results showed non significant variations between right and left ovaries in DNA damage (table 2). While the mean \pm SD of COMET \% in the right and left ovaries recorded significant variations between seasons in both tailed and non tailed DNA (table 2 and figures 8,9).

\section{DISCUSSION:}

Great attention in many regions of the world was directed toward camel research. It's the only animal that can survive for several weeks without water and still provide humans with meat and milk and transport in harsh, dry conditions (Agag, 1991). So, to improve the reproductive efficiency of this neglected animal, it is a must to investigate the cytogenetic variation in relation to reproductive performance in this species. DNA responsible of genetic information of each living cell integrity and stability are essential to life, DNA is not inert, chemical entity subject to assault from the environment of resulting damage if not repair lead to mutation (Moore and Haber, 1996). The electrophoresis technique is the current standard of reference for the fractionation of the serum proteins (SPE) in clinical biochemistry (Kaneko, 1997). Results from the present work indicated more marked differences between breeding and non breeding seasons for reproduction in she camel. This was elucidated by the concentrations of albumin recorded in breeding season which were higher than those recorded in non breeding season for she camel. Serious metabolic states are associated with higher concentration of albumin caused by the fact that the majority of acute phase protein occur in this fraction and some increases in the concentration of albumin (Tóthová et al., 2013, and Csilla et al., 2011). Higher values of albumin in she camel obtained in this study might be related to the exposure of animals to changing nutritional and rearing factors and/or associated with the normal processes of growth. Similarly, Chaudhary et al., (2003) stated that the differences between breeding and non breeding seasons observed in the concentration of albumin fractions may be due to the physiological factors. The current results were in accordance with those in horses, goat and camels that the age of investigated animals may markedly influence the electrophoretic pattern of serum proteins with decreasing albumin and increasing transferrin concentrations with advancing age (Alberghina et al., 2010). In the present study, agarose gel electrophoresis of serum protein in she camel samples identified fraction comprising albumin prealbmin, post albumin and transferrin. There are very few reports published about more detailed serum protein profiles in she camel and the data were obtained some years ago using different methods of electrophoresis. Bramel (2001) presented only the number and magnitude of 
Genetic analysis of blood protein and COMET assay on the ovary in relation to reproductive performance in shecamel (C. dromedaries)

protein fractions, without determination of relative concentrations and calculating of absolute values for each fraction. He separated serum protein in she-camel by paper electrophoresis into four fractions; albumin, prealbumin, postalbumin and transferrin. Compared with the current study. He obtained lower relative concentration for albumin. These variation in the concentration of serum protein fractions reported by various authors, might be affected by the used support media and also the electrophoretic techniques.

Quantitation of serum protein fractions determination, however, awaiting more researches because of only scarce literature available about the electrophoretic separation of serum proteins in she camel, further investigations in larger animal group are needed to yield satisfactory results. In the same aspect, Diao et al., (2004) reported that the various molecular processes especially at the protein expression level, in terms of germ cell, follicular growth, and the mechanisms by which ovarian hormones regulate ovarian cycles, including follicular maturation, ovulation, and corpus luteum formation. This is in part, because it is difficult to investigate the complex functions of the ovary.

Concerning COMET assay, it is simple method for measuring deoxyribonucleic acid (DNA) strand breaks in eukaryotic cells. Singlecell gel electrophoresis, commonly called a comet assay, is a simple and sensitive method for assessing DNA damage at the single-cell level. It is an important technique in genetic toxicological studies (Natalia et al., 2015; Pu et al., 2015). Cells embedded in agarose on microscopic slide are lysed with detergent and high salt to form nucleoids containing supercoiled loops of DNA breaks (Collins, 2004). Practically the entire tails moves in the direction of a changed electric field. The single strands in partially double stranded DNA will easily entangle with other DNA molecules in the lysed nucleus, which will inhibit their possibility to escape from the head of the comet in to the gel. The forked structure at the ends and the fact that partially single stranded fragments are bigger in size than the single stranded ones may inhibit the speed in the gel. There are thus two types of molecules with widely different travelling speeds. The tail and head are therefore clearly separated by a waist in alkaline gel in contrast to the continuous head and tail in neutral gels (Benjamin et al 1997).

In the same aspect, in Monkeys, Motohashi and Ishibashi (2016) reported that the comet assay, a single cell gel electrophoresis assay, is a simple and sensitive technique for detecting DNA damage at the level of the individual cell. The alkaline version of the COMET assay enables detection of single- and double-strand breaks in single cells. This technique has also been used to assess the cryodamage of the genomic DNA of cumulus cells, oocytes, and sperm. In addition, it is also possible to analyze the damage in cryopreserved somatic tissues. Therefore, the COMET assay is useful for evaluating the cryo-damage of cells following ovarian cryopreservation. The comet assay was performed to determine the extent of genomic DNA damage. The results of two different COMET parameters of the DNA percentage in the tail, was not significantly different between fresh and vitrified/warmed ovaries $(20.9 \pm 3.5$ vs. $25.8 \pm 1.9)$. The present results 
(table 2 and figures 7,8,9) showed a significant variation between the COMET DNA damage between seasons but not between the right and left ovaries. These findings were in coincidence with the fact that female camel is a seasonal breeder animal. It is well established that low levels of DNA strand breaks and genetic instability occur very early in chemically induced injuries and can make both immediate and long-term contributions to the development of mutations, cancer, and other effects in a variety of organs, both locally and peripherally (Midwood et al., 2004; Noble, 2008; Samoszuk, 2005; Polyak and Kalluri, 2010, Vasquez, 2012).

In similar approach but for spermatozoa, Mostafa et al. (2014) recorded COMET assay of spermatozoal DNA revealed that spermatozoa showing COMETs were higher in semen collected by EE than in AV, but the differences were not significant. They concluded that superiority of semen collection by AV on sperm DNA integrity of camel bulls as compared to EE method.

Concerning camelids, no available literature were reported concerning COMET assay for ovarian cells in she camel. The clinical significance of COMET in evaluating the cellular damage of DNA in dromedary camel would be of particular importance in evaluating the oocytes or even follicles before and after they subjected to in vitro fertilization and ICSI techniques.

\section{References}

Adams, G. P., Sumar, J. and Ginther, O. J. (1990): Effects of lactational and reproductive status on ovarian follicular waves in llamas. J Reprod Fertil 90, 53545 .

Agag, M.A. (1991): Studies on the reproductive function of male dromedary camel with special references to age and season. PhD Thesis, L.M.U. and Benha Univ., Germany and Egypt.

Ahmadi-Hamedani, M., Ghazvinian, K., Kokhaei, P., Barati, M. and Mahdavi, A. (2014):Comparison of effects of age and sex on serum protein electrophoretic pattern in one-humped camels (Camelus dromedarius) in Semnan, Iran. Open Vet J 4, 4-8.

Alberghina, D., Casella, S., Vazzana, I., Ferrantelli, V., Giannetto, C. and Piccione, G. (2010): Analysis of serum proteins in clinically healthy goats (Capra hircus) using agarose gel electrophoresis. Vet Clin Pathol 39, 317-21.

Andrew, R. (2004): the Comet assay for DNA damage and repair, Review, principle application and limitation, Molecular biotechnology, 26: 249-269.

Benjamin , E.N., Rich, M., Terry , R.,( 1997):Measuring Apoptosis in individual cells with the Comet Assay Promega Notes Number 64,13.

Benmoussa, M., Vézina, L.-P., Pagé, M., Yelle, S. and Laberge, S. (2000): Genetic polymorphism in low-molecular-weight glutenin genes from Triticum aestivum, variety Chinese Spring. Theoretical and Applied Genetics 100, 789-793.

Berek, J. S. and Martinez-Maza, O. (1994): Molecular and biologic factors in the pathogenesis of ovarian cancer. J Reprod Med 39, 241-8. 
Genetic analysis of blood protein and COMET assay on the ovary in relation to reproductive performance in shecamel (C. dromedaries)

Bramel, F. W. R. (2001): In Marshall's physiology of reproduction Vol. London Longmans. 112, 23-27.

Brown, P. W. (2000): Views on reproduction in South American camelids Aim .Reprod ,Sci., 58, 169-124.

Bruss, J. W. and Editors, M. L. (2000): Serum protein electrophoresis pattern in young and adult camels clnilical biochemistry of Domestic Animals 5Thedn Academic Press, New york 15: 120-138.

Caprette, D. (2009): What is the meaning of de gas the acrylamide gel mix?". Vet Rep $.55-67,55-67$.

Chaudhary, Z. I., Iqbal, J. and Rashid, J. (2003): Serum protein electrophoretic pattern in young and adult camels. Aust Vet J 81, 625-6.

Collins, A. R. (2004): The COMET assay for DNA damage and repair: principles, applications, and limitations. Mol Biotechnol 26, 249-61.

Cook, P. R., Brazell, I. A. and Jost, E. (1976): Characterization of nuclear structures containing superhelical DNA. J Cell Sci 22, 303-24.

Csilla, T. Osker, N. Herbert, S. (2011): serum protein electrophoretic pattern in clinically healthy calves and cow determined by agarose gel electrophoresis Com Clin Pathol 22-25.

Deen J. (2008)): Premature aging in mice deficient in DNA repair and transcription". Science 296 (5571).

Diao, F. Y., Xu, M., Hu, Y., Li, J., Xu, Z., Lin, M., Wang, L., Zhou, Y., Zhou, Z., Liu, J. et al. (2004): The molecular characteristics of polycystic ovary syndrome (PCOS) ovary defined by human ovary cDNA microarray. J Mol Endocrinol 33, 59-72.

Fayos, M., Couto, C. G., Iazbik, M. C. and Wellman, M. L. (2005): Serum protein electrophoresis in retired racing Greyhounds. Vet Clin Pathol 34, 397400.

Fernández-Baca, S. (1993): Manipulation of reproductive functions in male and female New World camelids. Animal Reproduction Science 33, 307-323.

Iliyasu, D., Bukar, M., Maina, A., Lawan, A., Raji, L., Stephen, J. and Abdulrahaman, U. (2016): Survey of Ovaries of Camels (Camelus dromedarius) for Dimensions and Abnormalities Responsible for Infertility and Sterility among Camels Slaughter at Maiduguri Abattoir, Nigeria. International Journal of Veterinary Papers $1,1-5$.

Kaneko, Y., Kimura, T., Kishishita, M., Noda, Y. and Fujita, J. (1997): Cloning of apg2 encoding a novel member of heat shock protein 110 family. Gene 189, 1924.

Keay, G. and Doxey, D. L. (1982): A comparison of the serum protein electrophoretic patterns of young and adult animals. Vet Res Commun 5, 271-6.

Masharov, A. M. (1980): Proposal on the nomenclature of genetic markers of farm animal and poultry. Biol Vet 33-39.

Mayer, K. H. and Fiechter, G. (2013):

Electrophoretic Techniques. In: 
Comprehensive Analytical Chemistry, 60: 251-278.

Midwood, K. S.; Valenick Williams, L.; Schwarzbauer, J.E. (2004): Tissue repair and the dynamics of the extracellular matrix. Int. J. Biochem. Cell Biol., (36) pp. 1031-1037

Minde, D. P., Maurice, M. M. and Rüdiger, S. G. D. (2012): Determining Biophysical Protein Stability in Lysates by a Fast Proteolysis Assay, FASTpp. 7: 46147.

Moore, J. K. and Haber, J. E. (1996). Cell cycle and genetic requirements of two pathways of nonhomologous end-joining repair of double-strand breaks in Saccharomyces cerevisiae. Mol. Cell. Biol. 16, 2164 2173.

Mostafa T.H., Abd El-Salaam A.M., Elbadry D.E., and Abear M. Anour (2014): Freezability and DNA integrity of dromedary camel spermatozoa in semen collected by artificial vagina and electroejaculator. Egyptian J. Anim. Prod., 51(2):145-155.

Motohashi, H. and Ishibashi, H. (2016): Cryopreservation of ovaries from neonatal marmoset monkeys. Experimental Animals 65 (3) p. 122.

Natalia Y. T., Arnold, I.V., and Shaofei Ji. (2015): DNA-Protein Cross-Links: Formation, Structural Identities, and Biological Outcomes. Acc. Chem. Res., 48 (6): pp 1631-1644

Navajas, M. and Fenton, B. (2000): The application of molecular markers in the study of diversity in acarology: a review. Exp Appl Acarol 24, 751-74.
Nawar, S. M. A., Abul- Fadl, W. S. and Shalah, A. M. (2001). Studies on the ovarian activity of the dromedary (camelus dromedaries). . J. Anat. Forsch. Leiping, 92, 34-45.

Noble, P. N. (2008): Epithelial fibroblast triggering and interactions in pulmonary fibrosis.

Eur. Respir. Rev., (17), pp. 123-129.

Polyak, K. Kalluri, R. (2010): The role of the microenvironment in mammary gland development and cancer. Cold Spring Harbor Perspect. Biol., (2), p. a003244

Pu, X., Wang ,Z, Klaunig, J. E. (2015): Alkaline Comet Assay for Assessing DNA Damage in Individual Cells. Curr. Protoc. Toxicol. 65 (3) 12: 1-11.

Rath, A., Glibowicka, M., Nadeau, V. G., Chen, G. and Deber, C. M. (2009). Detergent binding explains anomalous SDS-PAGE migration of membrane proteins. Proceedings of the National Academy of Sciences 106, 1760-1765.

Samoszuk, M.; Tan, J. and Chorn, G. (2005): Clonogenic growth of human breast cancer cells co-cultured in direct contact with serum-activated fibroblasts. Breast Cancer Res., (7), pp. 274-283.

Sinha, R. K., Thakuris, B. N., Baruah, R. N. and Sarma, B. C. (1981): Effect of breed, age, sex and season on total serum cholesterol level in cattle. Indian veterinary journal v. 58 .

Skidmore, A. (2010): Reproduction physiology in female camel in lecture notes for the short course in the dromedary camel, Skidmore(ED)int Vet information service theca N. Y. 23-44. 
Genetic analysis of blood protein and COMET assay on the ovary in relation to reproductive performance in shecamel (C. dromedaries)

SPSS Inc. (2007): SPSS for Windows, Version 16.0. Chicago, SPSS.

Taylor, S. S., Tappin, S. W., Dodkin, S. J., Papasouliotis, K., Casamian-Sorrosal, D. and Tasker, S. (2010): Serum protein electrophoresis in 155 cats. $J$ Feline Med Surg 12, 643-53.

Xu, Y. S., Wang, H. Y., Zeng, G. Q., Jiang, G. T. and Gao, Y. H. (1985): Hormone concentrations before and after semeninduced ovulation in the bactrian camel
(Camelus bactrianus). J Reprod Fertil (74): 341-6. 